\title{
Pitymys Mc. Murtrie 1831 (Microtidae, Rodentia) in the Northern Carpathians
}

\author{
Pitymys Mc. Murtrie 1831 (Microtidae, Rodentia) \\ w pólnocnej części Karpat
}

\section{INTRODUCTION}

In $1952 \mathrm{~J}$. K r a to $\mathrm{chvil}$ rewised all the materials of Pitymys M c. M u rtrie 1831 from Czechoslovakia and distinguished among them three forms: Pitymys subterraneus subterraneus (de Sélys L o ng champs 1836) distributed over Bohemia, Morava and mountaineous parts of Slovakia, an unnamed form with slightly longer tail and hind foot living in the southern Slovakia and a new species, Pitymys tatricus $\mathrm{Kratochvil} 1952$ from the alpine zone of the High Tatra Mts. In the same paper J. Kratochvil discusses all the described forms of the genus Pitymys M c. M u r. from the region of the Carpathians and states, that most of the descriptions are based on inadequate characters (colour changes) or on unsufficient material. The paper of J. Kratochvil contains exclusively the descriptions of the fur and the external dimensions of animals, it lacks date concerning the skull and the dentition. The new species, $P$. tatricus $\mathrm{K} \mathrm{r}$ a t., was compared only with $P$. s. subterraneus (d e S él. Long) and $P$. ehiki W et ts t e in 1927. The author did not select a holutype.

In the last years the difficult problem of systematics of European representatives of the genus Pitymys $\mathrm{M} \mathrm{c}$. M u r. was partly cleared in the work of J, Ellerman \& T, C. S. Morrison- 
S c o t t (1951), which group all described forms in three species: $P$. subterranerus (de Sélys Long cha $\mathrm{mps}$ 1835), $P$. savii (de Sélys Longchamps 1838) and P. duodecimcostatus (de Sélys Longchamps 1839). The investigations of $R$. M a t they (1955) confirm this division on the basis of chromosome numbers, but they also show that $P$. multiplex (F a tio $1905)$ is a distinct species with a different cytological pattern. The arrangement of subspecies of P. subterraneus (d e S é l. Lo n g.) in the work of Ellerman \& Morrison-Scott is, unfortunately, purely mechanical and the problem of geographical variation in this species is still open. Cytological research must decide if the forms of Pitymys $\mathrm{M} \mathrm{c}$. M u r. living in the Caucasus and Little Asia are different species, as stated by S. I. O gnev (1950) or only subspecies of the European forms, as stated by Ellerman \& Morrison-Scott.

From the northern slopes of the Carpathians the occurrences of burrowing-voles were cited from the territory of Ukraina, namely from the Czarnohora Mts. (L. S a g a n, 1939; A. T a ta rinov, 1956) and from the territory of Poland: from Podkarpacie (W. S k uratowicz \& E. Warchalewski, 1954), Western Bieszczady Mts. (W. Grodziński, 1957), and Western Beskidy Mts. (W. Grodzińs ki, 1958).

In the present paper the burrowing-voles from Czarnohora, W. Bieszczady, Beskid Niski, High Tatra and W. Beskidy (vicinity of Jordanów and Babia Góra) are described; the author studied 40 specimens from these localities. The specimens from Western Bieszczady Mts. and from Jordanów were collected by mgr W. G rodziń$\mathrm{ski}$ to whom I am very indebted for the permission to publish about these specimens. The rest of the specimens is preserved in the Cracow Branch of the Zoological Institute, Polish Academy of Sciences. They were collected by L. S a g a n, J. S a g a n and by the writer. I took into account in my paper the description of the specimens of Pitymys M c. M u r. from Poland by Z. D zi edu s z y c$\mathrm{k}$ a (manuscript in the Zoological Institute, Polish Academy of Sciences). I used in this work, as comparative material, a part of the large collection of P.s. subterraneus (d e S él. Long.) from Białowieża National Park, which is preserved in the Mammals Research Institute of the Polish Academy of Sciences. I also wish to thank Prof. August D e hnel for the permission tu study these 


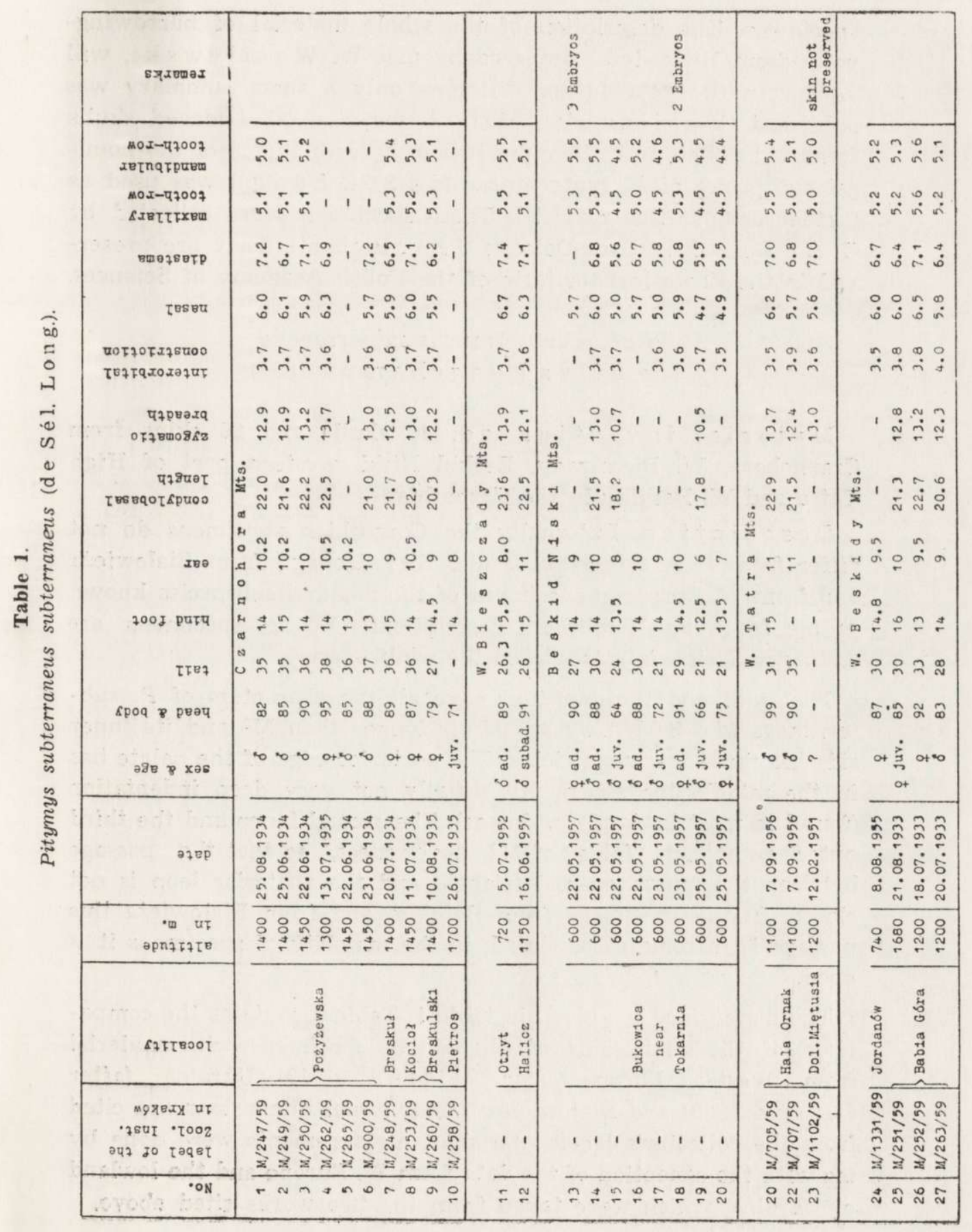


specimens. The description of the whole material of burrowingvoles from Białowieża, prepared by mgr W. W a sil ew ski, will appear in the near future; till now only a short summary was published (W a silewski, 1959). A series of 20 damaged skulls from owl pellets from Belgium [which is terra typica of the nominal subspecies of $P$. subterraneus (d e S él. Long.)] was used as further comparative material. These specimens were collected by G. D e B lock in Grez-Doiceau (Prov. Brabant). They are preserved in the Zoological Institute of the Polish Academy of Sciences.

$$
\begin{aligned}
& \text { Pitymys subterraneus subterraneus } \\
& \text { (de S ély s Long champs 1836) }
\end{aligned}
$$

Material investigated: 26 skulls and 26 skins from Czarnohora, W. Bieszczady, Beskid Niski, western part of High Tatra and W. Beskidy in the Carpathians.

Description. Externally the Carpathian specimens do not differ from P. s. subterraneus (d e Sél. L ong.) from Białowieża and from W. European specimens of the nominal subspecies known to me from the published descriptions. Young specimens are distinctly darker in colour then the adult ones.

The skull and the dentition have all the characters of $P$. subterraneus (de Sél. Long.): $\mathrm{M}^{3}$ is longer than $\mathrm{M}^{2}$ and its inner side has three re-entrant folds. The posterior edge of the palate has in the middle the sharp, but usually not very deep indentation (found in most lowland specimens). The second inner and the third outer re-entrant folds of $\mathrm{M}^{3}$ never meet, so that the passage between the fourth enamel triangle and the posterior loop is not closed. In the specimens from Belgium and from Białowieża this passage is in some cases closed, in the majority of specimens it is open.

The dimensions are given in table 1 . Table 3 contains the comparison of the dimensions of Carpathian specimens with material from Western Europe (after Miller, 1912), Ukraina (after O g n e v, 1950) and Białowieża. The external dimensions are cited from the collector's labels, the skull measurements were done by me with the exception of the data from W. Europe and the lowland of Ukraina, which were taken from the two works cited above, 


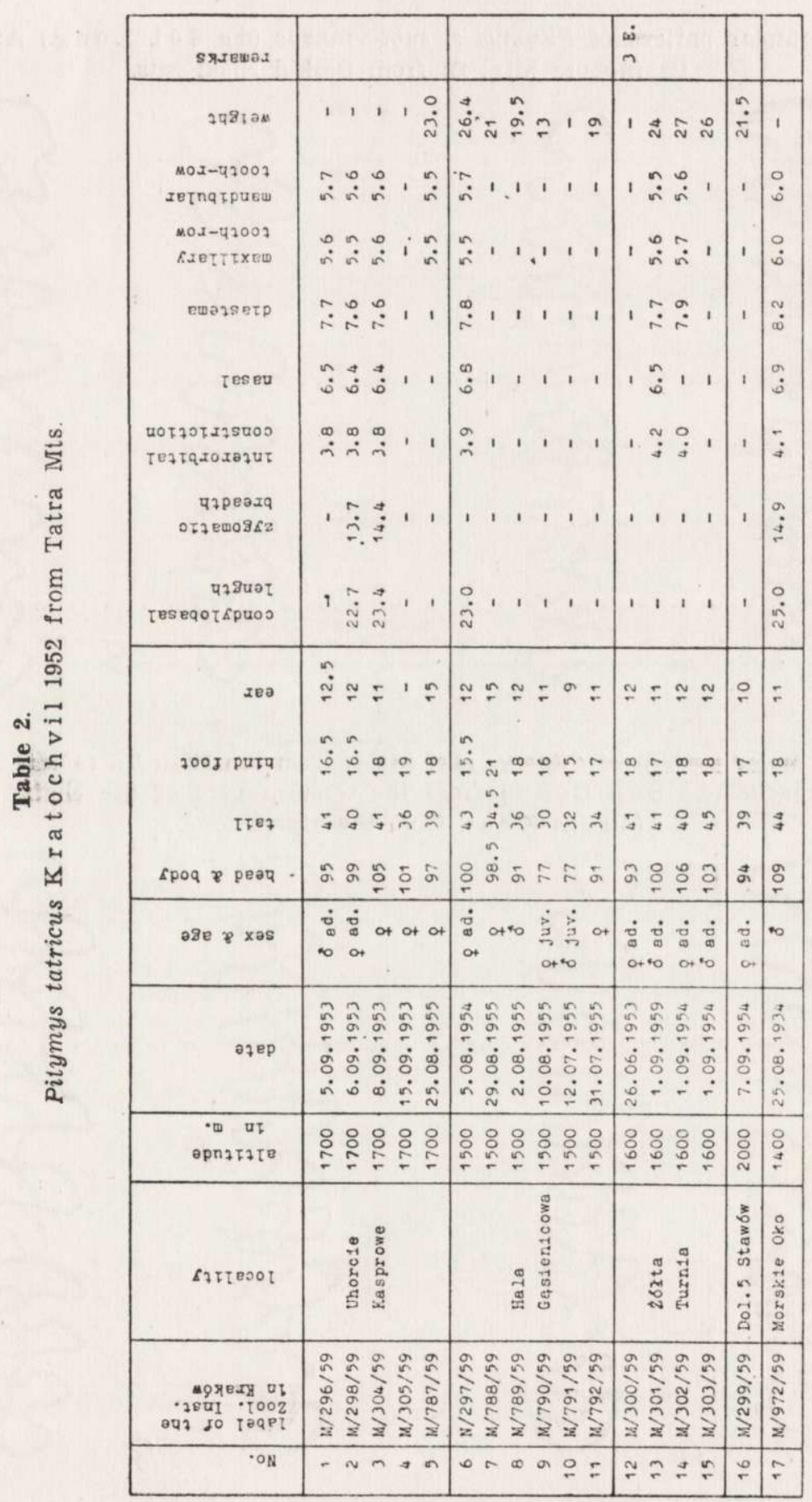


Fig. 1. Molar pattern of Pitymys s. subterraneus (de Sél. Lon g.) A: from Czarnohora Mts., B: from Beskid Niski Mts.
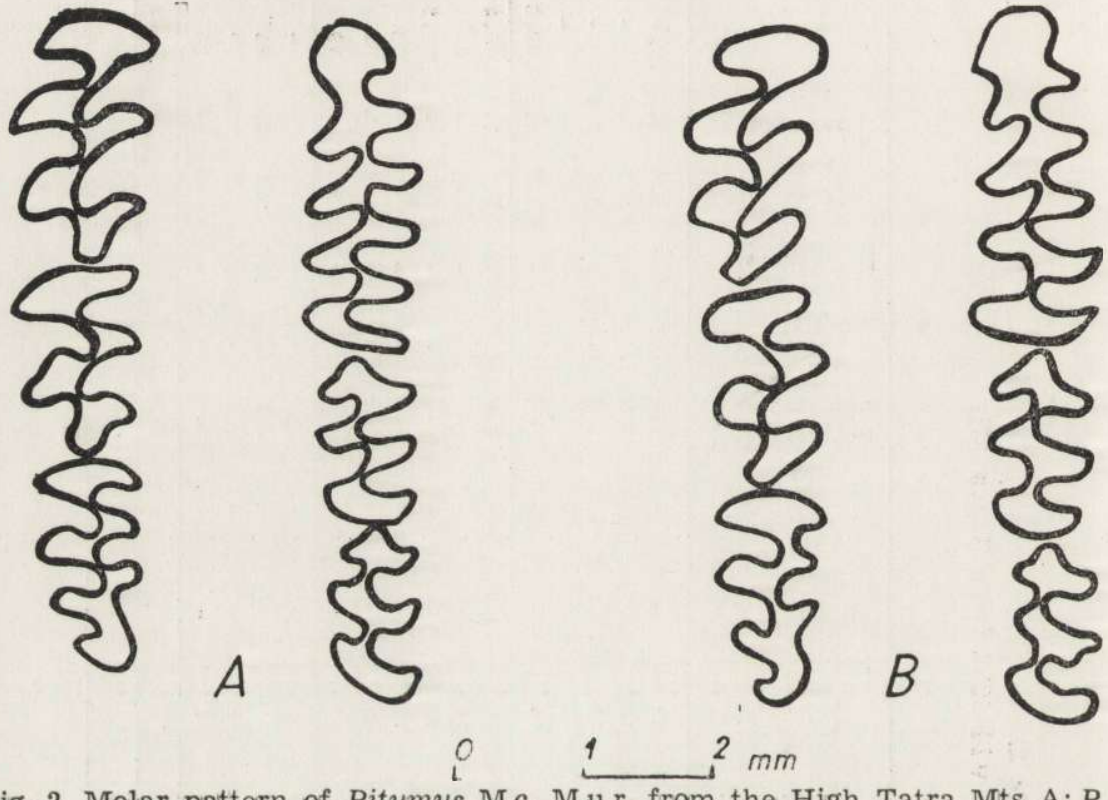

Fig. 2. Molar pattern of Pitymys M c. Mur. from the High Tatra Mts. A: P.s. subterraneus (de Sél. Long.) from the western part of the chain, B: $P$.
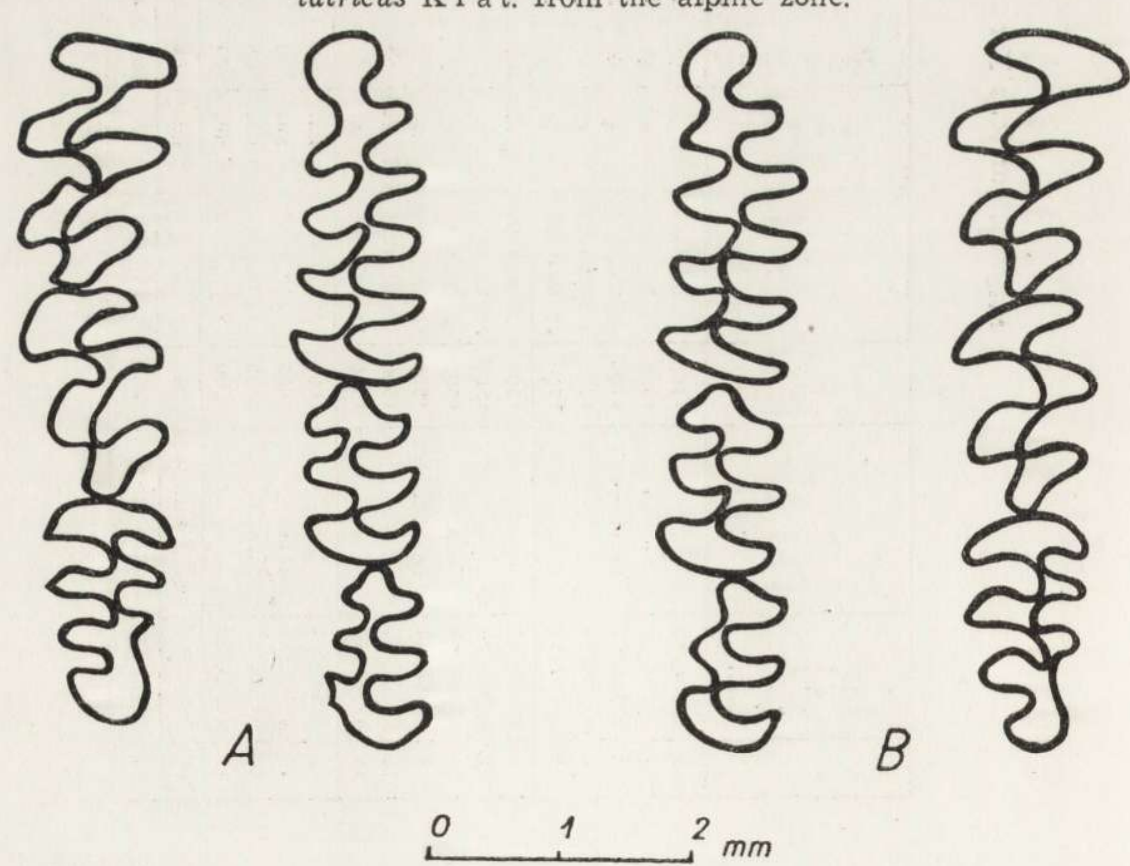
Pitymys tatricus Kratochvil 1952

Material investig a ted: 16 skins and 8 skulls from the Polish part of the High Tatra Mts.

Description. Externally similar to P.s. subterraneus (d e S él. Long.), but tail longer (absolutely and relatively). The colour of the fur is slightly different from that in the specimens from other parts of the Carpathians and from Białowieża: it is lighter, more yellowish and without the red hue which dominates in the other populations.

The skull in all its dimensions is greater than in the specimens from lowlands and from other localities in the Carpathians. On the posterior edge of the palate the middle indentation is flat; in some specimens this edge forms an arch and is not divided into three indentations. In $\mathrm{M}^{3}$, in all the investigated specimens, the second inner re-entrant fold meets the third outer one, so that the fourth enamel triangle is completely closed from the posterior loop. This character can be seen in only some individuals of the lowland population.

The dimensions are given in tables 2 and 3.

\section{GENERAL REMARKS}

In the Northern Carpathians live two different forms of the genus Pitymys $\mathrm{M}$ c. M u r. One of them is distributed on the northern slopes of this mountains and goes up in Czarnohora and Western Beskidy to $1700 \mathrm{~m}$ a.s.l. and probably even higher, to the highest peaks of these chains. It is distributed also over High Tatra Mts., where it lives on meadows amidst forest in lower parts of the chain. Our material is unsufficient for definite statements, but it indicates that in the Northern Carpathians and northward from these mountains live the nominal subspecies P.s. subterraneus ( $\mathrm{d}$ Sél. Long.). The population from Białowieża has somewhat smaller dimensions than the materials known from Belgium, from Ukraina and from Carpathians.

Another form of burrowing-vole, described as P. tatricus $\mathrm{K} r$ a t. occurs at the hights of about $1400-2000 \mathrm{~m}$ a.s.l., and probably even higher, above the tree-line in the High Tatra Mts. It differs in external dimensions, in the colour of the fur and in skull dimensions, 


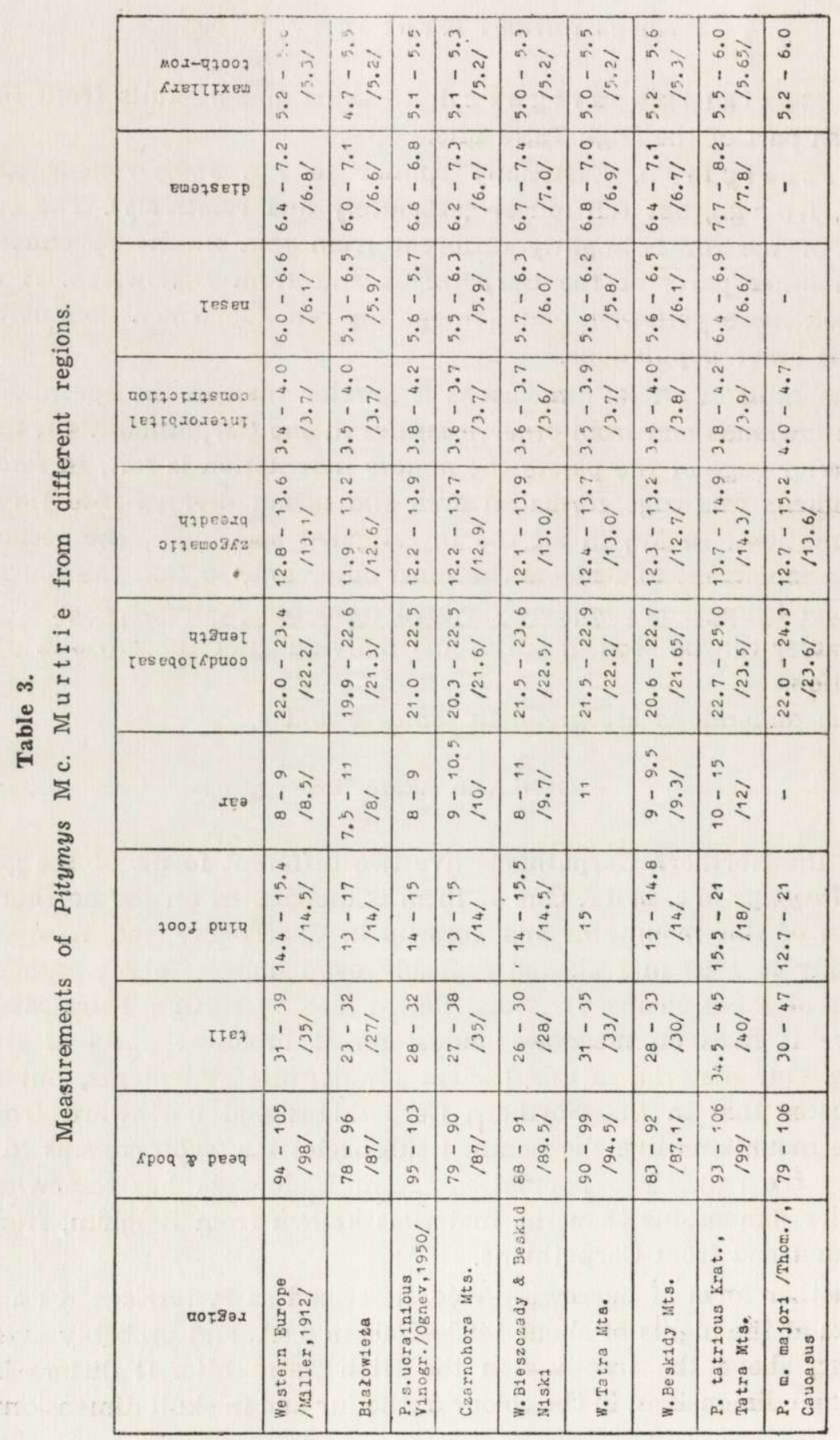


from the specimens living in other parts of the Carpathians and in the lowlands. In the light of the systematics of E 1 l er m a n \& M or$\mathrm{r}$ is o $\mathrm{n}-\mathrm{S} \mathrm{c}$ ot t (1951) this form belongs to $P$. subterraneus (d e Sél. Long.), with which it has in common such characters as the relation of the length of $\mathrm{M}^{2}$ to $\mathrm{M}^{3}$, length of the diastema in relation to the condylobasal length of the skull etc. The dimensions of the High Tatra form are nearly the same as those of P. majori (Thomas), which is considered by Ellermann \& Morri$\mathrm{s}$ o $\mathrm{n}-\mathrm{S}$ c o t t (1951) as a subspecies of $P$. subterraneus (d e Sél. $\mathrm{L}$ on g.) The differences between T. tatricus $\mathrm{K} \mathrm{r}$ a t. and P.s. subterraneus (d e S él L o n g.) are no greater than between many of the subspecies of other species of microtines. The definitive solution of the problem of specific or subspecific rank of $P$. tatricus $\mathrm{K} r$ a t. can be only done through cytological research and the cross-breeding with other forms.

\section{SUIMIMARY}

In the northern part of the Carpathians live two forms of the genus Pitymys M c. M u rtrie 1831. One of them, P.s. subterraneus (d e Sélys Longchamps 1836), is distributed over Podkarpacie, Czarnohora, Bieszczady, Beskid Niski and Western Beskidy Mts., as well as over the western parts of the High Tatra Mts., ranging at least to $1700 \mathrm{~m}$ a.s.l. The author gives the description of 27 specimens from the named areas comparing them with the materials from Belgium and from Białowieża National Park (Northern Poland).

In the Polish part of the High Tatra Mts lives the peculiar form of the burrowing-vole, described and known till now from the Slovak part of this mountains as Pitymys tatricus Kratochvil 1952. This form belongs to the group of P. subterraneus (d e S él. L o ng.), its specific or subspecific status can be decided only on the basis of biological and cytological investigations. The description and dimensions of the skull and dentition of P. tatricus $\mathrm{Krat}$. are published and its resemblance to $P$. majori ( $\mathrm{T}$ hom as 1906) from the Caucasus is listed.

\section{Polish Academy of Sciences, \\ Zoological Institute, Cracow Branch.}

Kraków, Slawkowska 21. 


\section{REFERENCES}

1. Ellerman, J. R. \& Morrison-S cot t, T.C.S. Checklist of Palaearctic and Indian Mammals. British Museum. 1-810. London, 1951.

2. Grodziński, W., Materiały do fauny kręgowców Bieszczad Zachodnich. Zeszyty Naukowe U.J., Zoologia 1: 177-221, 7 tb. Kraków, 1957.

3. Grodzinski, W. The Succession of Small Mammal Communities on an Overgrovn Clearing and Landslip in the Western Carpathians. Bull. Acad. Pol. Sc., Cl. II, Vol. 6, 10: 431-439. Warszawa, 1958.

4. Kratochvil, J. Hraboši rodu Pitymys McMurtri e v Ceskoslovensku. Prace Moravskoslezské Ak. Ved. Přir., Vol. 24 (8) 5: 155-194. Brno, 1952.

5. M a they, R. Nouveaux documents sur les chromosomes des Muridae. Problèmes de cytologie comparée et de taxonomie chez les Microtinae. Revue Suisse de Zool., Vol. 62, 1: 163-206. Genève, 1955,

6. Miller, G. S. Catalogue of the Mammals of Western Europe. Brit. Mus. I - XV, 1-1019. London, 1912.

7. Ognev, S. I. Огнев, С. И. Звери СССР и. приналежащих стран. 7. АН СССР. 1-706. Москва-Ленинград, 1950.

10 pls., 14 cards. Moskva-Leningrad, 1950.

8. S a g a n, L. Ssaki (Mammalia). Przyczynek do znajomości gryzoni Czarnohory. Rozprawy i Spraw. Inst. Bad. Lasów Państw. Ser. A, no. 42: 48-54. Warszawa, 1939.

9. Skuratowicz, W. \& Warchalew ski, E. Przyczynek do fauny drobnych ssaków Podkarpacia. Prace Kom. Biol. Pozn. Tow. Przyj. Nauk, Vol. 15, 2: 1-9. Poznań, 1954.

10. таtarinov, K. А. Татаринов, К. А. Звірі західних областей України. АН УРСР. 1-187. Київ, 1956.

11. Wasilewski, W. Badania nad zmiennością morfologiczną darniówki Pitymys subterraneus (de Sél. Long.) w Puszczy Bialowieskiej. Zjazd Anatomów i Zoologów Polskich. Streszczenia Referatów: 553-554. Kraków, 1959.

\section{STRESZCZENIE}

W r. 1952 J. Kratoch vil opisał z terenu Tatr Slowackich nowy gatunek darniówki Pitymys tatricus $\mathrm{Kr}$ atochvil 1952. Praca tego autora zawiera jedynie wymiary zewnętrzne i opis ubarwienia nowej formy oraz jej porównanie $\mathrm{z}$ materialem darniówek $\mathrm{z}$ innych terenów Czechoslowacji. Zagadnienie systematyki rodzaju Pitymys M c. M u rtri e 1831 uległo wyjaśnieniu dzięki pracom J. Ellermana \& Morrison-Scotta (1951) oraz M atthe y a (1955), które pozwoliły stwierdzić, że na terenie Europy żyją 4 gatunki tego nodzaju. Zmienność geograficzna w obrębie najszerzej rozmieszczonego gatunku Pitymys subterraneus (de Sélys Longchamps 1836), jak również stanowisko systematyczne małoazjatyckich i kaukaskich form darniówek nie zostało jeszcze ostatecznie wyświetlone.

$\mathrm{Z}$ terenu północnej części Karpat darniówka podawana była z Podkarpacia, Czarnohory, Bieszczad Zachodnich i Beskidu Zachodniego. 
Praca niniejsza zawiera opis 40 akazów darniówek z Czarnohory, Bieszczad Zachodnich, Beskidu Niskiego, Tatr i Beskidu Zachodniego. Jako materiał porównawczy posłużyła seria okazów z Białowieży oraz seria czaszek darniówek ze zrzutek sów z Belgii.

Na północnych stokach Karpat żyje Pitymys subterraneus subterraneus (de Sélys Longchamps 1836) dochodząca w Czarnohorze i w Beskidach Zachodnich do wysokości $1700 \mathrm{~m}$ n.p.m., a prawdopodobnie wyżej, aż do najwyższych wierzcholków tych pasm. Ta sama odmiana występuje również na śródleśnych ląkach w Tatrach Zachodnich. Karpacka populacja darniówek nie różni się od materiału z Belgii, natomiast materiał z Białowieży odznacza się nieco mniejszymi rozmiarami ciała i czaszki (Tabela 1).

W polskiej części Tatr Wysokich, ponad górną granicą lasu, na wysokości 1400-2000 m n.p.m., a prawdopodobnie i wyżej, żyje populacja darniówki o odmiennych cechach. Jest to forma opisana jako Pitymys tatricus $\mathrm{K} \mathrm{ra-}$ t o chvil 1952. Odróżnia się ona od populacji nizinnych oraz populacji z innych części Karpat większymi rozmiarami ciała i czaszki, proporcjonalnie dłuższym ogonem oraz odmiennym tonem ubarwienia, w którym przeważa odcień płowy. W $\mathrm{M}^{3}$ u populacji tatrzańskiej występuje we wszystkich badanych przypadkach takie ukształtowanie pętli szkliwa, przy którym druga zatoka wewnętrzna i trzecia zewnętrzna stykają się z sobą. Cechy tej nie zauważono u żadnego z badanych okazów z innych części Karpat, u okazów nizinnych występuje ona $\mathrm{w}$ kilku procentach okazów. Wymiary okazów darniowek z Tatr Wysokich podano w tabeli 2 .

Sprawa odrębności gatunkowej czy tylko podgatunkowej Pitymys tatricus Krat. wymaga dalszych badań, przede wszystkim przez poznanie liczby chromosomów i próby krzyżowania. Wymiarami populacja tatrzańska zbliża się do kaukaskiej $P$. majori ( $\mathrm{T}$ hom as 1906). Tabela 3 podaje zestawienie wymiarów darniówek $\mathrm{z}$ różnych obszarów karpackich oraz z Europy Zachodniej, Białowieży, nizinnej części Ukrainy i Kaukazu. 


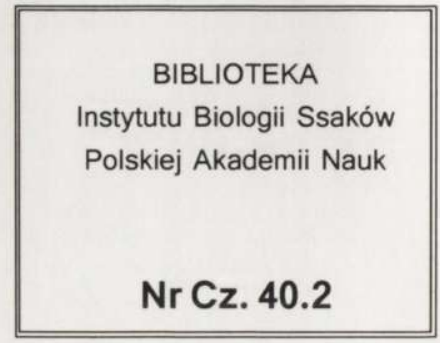

